\title{
APPRAISAL LEVEL TINGKAT PENETAPAN NJOP PAJAK BUMI DAN BANGUNAN DI KECAMATAN LOWOKWARU KOTA MALANG
}

\author{
Sri Andriani
}

Fakultas Ekonomi,Universitas Islam Negeri Maulana Malik Ibrahim Malang Jl. Gajayana 50 Malang Telp. 0341-551354 Faks. 0341-572533

email: sriandrianiuin@gmail.com/No Telepon 081333689915

\begin{abstract}
Appraisal level determination to NJOP (Tax Object Sale Value) land and building is a measurement of the tax object sale value is used to determine besarya property tax to be paid to the government's taxpayers. While the standard used to determine in an international NJOP is the standard IAAO (International Association of Assesor Officer). Analysis of measurements with HJOP NJOP adjustment is to use ratio analysis, Coefficient of Dispersion (COD), Non-Parametric Binomial Test, Spearman Correlation, compare Mean One Sample Test. The results of the determination of the ratio analysis NJOP ground (earth) in Dinoyo has qualified for justice, while not yet eligible, In Merjosari justice, the non-parametric binomial test showed the results has been no justice from all parties and interest in the determination of both Dinoyo NJOP or in the Merjosari. Uniformity NJOP Dinoyo level determination and Merjosari Malang District Lowokwaru significantly lower, this means setting performance NJOP is not good. There is a correlation between the appraisal value with NJOP HJOP as market values. There are significant differences in the determination of both NJOP compared HJOP Dinoyo or in the Merjosari.
\end{abstract}

Kayword: Appraisal Level, Appraisal Value, Market Value, NJOP, HJOP

\section{PENDAHULUAN}

Pasal 33 UUD 45 (Amandemen) menyatakan bahwa bumi, air, dan kekayaaan alam yang ada didalamnya dikuasai oleh negara dan dimanfaatkan sebesar-besarnya untuk kemakmuran rakyat. Peran dan fungsi bumi (tanah) menjadi suatu hal yang sangat penting baik bagi pemerintah maupun masyarakat. Bagi pemerintah fungsi tanah bisa sebagai aset yang dapat dimanfaatkan untuk fasilitas umum seperti rumah sakit, sekolah, sarana olah raga ataupun sarana ibadah yang dapat memberikan nilai manfaat kepada mayarakat secara langsung. Bagi masyarakat tanah (bumi) dan bangunan akan memberikan nilai manfaat berupa 
pendapatan dari tanah yang dikelola baik itu untuk pertanian maupun untuk kegiatan parkir (disewakan) yang dapat memberikan kepuasan secara pribadi.

Sehingga wajar apabila masyarakat ataupun yayasan yang memanfaatkan tanah tersebut diminta untuk menyerahkan sebagian dari kenikmatan yang diperolehnya dari pengusahaan tanah tersebut kepada negara melalui pembayaran pajak bumi dan bangunan. Hal ini tentunya sesuai dengan pasal 33 UUD 1945 (Amandemen) tesebut diatas.

Dalam mencerminkan keikutsertaan masyarakat dibidang pembiayaan pembangunan, maka semua objek pajak dikenakan pajak. Pasal 2 (1) UU No. 12 tahun 1985 sebagaimana diubah dalam UU No. 12 tahun 1994 tentang pajak Bumi dan Bangunan (PBB) menegaskan bumi dan/atau bangunan sebagai objek pajak dikenakan PBB. Dasar pengenaan pajak atas bumi dan/bangunan tersebut adalah Nilai Jual Objek Pajak (NJOP). NJOP adalah harga ratarata yang diperoleh dari transaksi jual beli secara wajar dan bilamana tidak terdapat transaksi jual beli, NJOP ditentukan melalui perbandingan harga dengan objek pajak lain yang sejenis atau nilai perolehan baru atau NJOP pengganti.

Dari pengertian tersebut dapat dipahami: (1) Pengertian NJOP tidak sama dengan nilai pasar. NJOP merupakan harga rata-rata suatu objek pajak yang ditetapkan dengan mekanisme tertentu, sedangkan nilai pasar dinyatakan sebagai Harga Jual Objek Pajak (HJOP) yang terjadi secara wajar dipasar. Oleh karena itu besar kemungkinan dapat terjadi HJOP yang ditentukan pasar lebih rendah, sama atau lebih tinggi dari HJOP yang ditetapkan pemerintah; (2) Penetapan NJOP dilakukan dengan mekanisme tertentu. Ini berarti bahwa penetapan NJOP tidak dilakukan dengan semaunya, tidak semata-mata menekankan unsur subjektivitas, akan tetapi dilakukan dengan ilmu tertentu, pendekatan tertentu dan mekanisme tertentu sesuai dengan Kep-537/PJ/2000 mengenai petunjuk teknis pendataan dan penilaian, yang demikian dimaksudkan supaya menghasilkan kinerja penetapan yang adil, akurat, transparan dan diterima semua pihak untuk segala kepentingan; (3) Penetapan NJOP ditetapkan oleh Menteri Keuangan. Ini mengandung pengertian bahwa kewenangan penetapan NJOP untuk semua orang dan segala kepentingan hanya dipegang oleh Menteri Keuangan. Dengan demikian dapat dihindarkan terjadinya NJOP yang berbeda-beda untuk satu objek pajak; (4) Penetapan NJOP, ditetapkan setiap tiga tahun, kecuali untuk daerah tertentu ditetapkan setiap satu tahun sesuai dengan perkembangan daerahnya, terutama kemajuan nilai ekonomis tanah suatu daerah. 
Berkaitan dengan nilai tanah suatu daerah, biasanya kantor pelayanan PBB dalam melakukan penilaian memprioritaskan pada daerah-daerah maju dan telah terdata melalui Proyek Sistem Manajemen Informasi Objek Pajak (SISMIOP),

Sekarang ini eksistensi NJOP PBB tidak hanya sekedar sebagai dasar pengenaan PBB, tetapi dapat juga digunakan kepentingan lainnya, antara lain adalah: (1) Keppres No. 55 tahun 1993 tentang pengadaan tanah bagi pelaksanaan pembangunan untuk kepentingan umum. Pasal 15 menyebutkan bahwa NJOP dijadikan sebagai dasar pertimbangan dalam penetapan besarnya ganti rugi atas tanah; (2) Peraturan pemerintah No. 27 Tahun 1996 juga menggunakan data NJOP sebagai dasar pengenaan PPh atas transaksi tanah dan/atau bangunan yang bernilai diatas Rp. 60.000.000,00; (3) UU No. 20 tahun 2000 tentang Bea Perolehan Hak Atas Tanah dan Bangunan (BPHTB).

Dengan banyaknya kepentingan masyarakat terhadap NJOP dapat menyebabkan reaksi ketidaksetujuan terhadap NJOP yang ditetapkan, manakala ketetapan NJOP tersebut lebih tinggi dari HJOP, kecuali bagi golongan masyarakat yang mempunyai kepentingan terhadap NJOP cukup tinggi, yang secara ekonomis justru menguntungkan mereka. Misalnya mereka yang berkepentingan atas ganti rugi tanah, jika harga tanah lebih dengan ketetapan NJOP yang ditetapkan pemerintah, walaupun bila dikaitkan dengan pelunasan PBB terhutang mereka belum tentu menerima NJOP tersebut.

Oleh karena itu, penetapan NJOP idealnya merupakan satu nilai yaitu, siapapun yang menetapkan dan siapapun yang mempergunakan ketetapan itu baik untuk perpajakan, asuransi, jaminan bank, ganti rugi dan sebagainya, ketetapan NJOP harus wajar/adil yang dapat diterima oleh semua pihak untuk segala kepentingan.

Untuk mengusahakan kewajaran/keadilan dalam penetapan NJOP maka peranan penilai PBB sangat menentukan. Eckert et al. (1990:16) menjelaskan bahwa peranan penilai untuk perpajakan adalah melakukan appraisal atau estimasi nilai properti. Estimasi nilai properti adalah pendapat atau taksiran subjektif dari penilai yang nilainya sama dengan nilai pasar properti tersebut pada saat penilaian dilakukan. Dan level of appraisal hendaknya mendekati $100 \%$.

Hasil estimasi nilai objek PBB ini tak lain adalah NJOP. Selanjutnya penetapan NJOP dikatakan wajar/adil jika NJOP mendekati HJOP (harga jual objek pajak), namun demikian, penetapan NJOP yang wajar/adil tersebut tidak terlepas dari keakuratan hasil estimasi penilai. 
International Association of Assesor Officer (IAAO) sebagaimana dikutip Eckertet al (1990:515) menegaskan bahwa keberlangsungan suatu ad valorem tax (pajak kebendaan) bergantung pada sejauh mana keakuratan appraisal dilakukan. Oleh karena itu menurut Hartoyo (1955:1) yang semestinya dilakukan adalah mengevaluasi kualitas kinerja penetapan NJOP tersebut dengan suatu alat yang dikenal dengan studi rasio.

Studi rasio digunakan untuk mengevaluasi kualitas penilaian untuk penetapan NJOP pada tingkat keseragamannya. Kualitas penilaian untuk penetapan NJOP akan semakin baik jika tingkat keseragaman penetapan NJOP suatu daerah semakin tinggi atau tingkat dispersinya semakin rendah. Dan apabila tingkat keseragamannya semakin rendah dan tingkat dispersinya tinggi, maka penetapan NJOP tersebut dikatakan buruk. Biasanya untuk melakukan penilaian ulang Kantor Pelayanan PBB memprioritaskan ada daerah yang telah terdata dan perkembangan nilai tanahnya pesat. Karena itu perlu juga dianalisa seberapa kuatkah hubungan antara NJOP dengan HJOP tanah di daerah tersebut.

Beberapa hal yang dapat diangkat menjadi permasalahan adalah (1) Apakah penetapan NJOP tanah (bumi) dan bangunan tidak terjadi over-appraisal atau under-appraisal?, (2) Apakah kualitas penilaian untuk penetapan NJOP tanah (bumi) dan bangunan telah baik? (3) Apakah ada korelai positif NJOP tanah (bumi) dan bangunan dengan HJOP tanah (bumi) dan bangunan? (4) Apakah ada perbedaan signifikan dalam penetapan HJOP tanah (bumi) dan bangunan?

Jika permasalahan tersebut dapat dianalisa maka kontribusi yang dapat diambil adalah (1) Diharapkan mampu memberikan masukan bagi pengambil keputusan pada Kantor Pelayanan Pajak Bumi dan Bangunan (KPP Bumi dan Bangunan) setempat untuk lebih memperhitungkan NJOP (Nilai Jual Objek Pajak) sebagai penentu perhitungan pajak bumi dan bangunan yang mendekatai Nilai wajar, sehingga lebih bisa meningkatkan penerimaan pajak. (2) Memberikan penilaian atas tanah (bumi) dan bangunan yang menguntungkan semua pihak (3) Diharapkan dapat membantu mahasiswa, peneliti, dan lainnya untuk mengembangkan penelitian ini lebih lanjut.

\section{KAJIAN TEORI DAN HIPOTESIS}

International Association of Assesor Officer (IAAO) 
International Association of Assesor Officer (IAAO) adalah sebuah organisasi pendidikan penelitian Internasional yang menyediakan jasa profesi penilaian property dan hal lain yang berhubungan dengan pajak property yang berpusat di pusat kota Chicago, di the Prudential Plaza 130 East Randolph Street, Suite 850.P

Sebagian besar anggota IAAO adalah orang-orang peniali property yang biasanya bekerja untuk pemerintah, tapi pada dasarnya juga terbuka bagi siapapun yang bekerja untuk industri, akademik atau bidang-bidang umum lainnya yang beminta dengan penilaian property.

Alasan penggunan Standart Penilaian dari International Association of Assesor Officer (IAAO) tersebut adalah karena sampai sekarang Direktorat Jendral Pajak Bumi dan Bangunan, sebagai institusi pusat selama ini belum memberikan standar studi rasio secara tegas. Seharusnya sebagai Institusi perpajakan selalu menjaga standar ratio pada suatu kawasan administrasi tertentu. Dengan adanya stadar tersebut dapat meningkatkan proses penilaian dan menjamin konsistensi kegiatan reappraisal ataupun kegiatan lain dalam rangka mendapatkan uniformity atau assessment tertentu. Karena itu dalam hal ini International Association of Assesor Officer (IAAO) pada tahun 1990, merekomendasikan standar studi rasio, yang meliputi :

\section{a. Standart Level Assesment}

Bagi Keseluruhan jenis property level assessment yang diisyaratkan adalah antar 0,90 sampai dengan 1,10 .

\section{b. Standar Uniformity}

Tabel 1: Standard Uniformity IAAO (International Association of Assesor Officer)

\begin{tabular}{|l|l|l|}
\hline No. & Jenis properti & COD \\
\hline 1 & Singgle Family Residances & $15 \%$, atau $<$ \\
\hline 2 & $\begin{array}{l}\text { Properti menghasilkan } \\
\text { Untuk wilayah yang lebih luas dengan } \\
\text { jenis properti yang sama }\end{array}$ & $\begin{array}{l}20 \% \text {, atau }< \\
15 \% \text {, atau }<\end{array}$ \\
\hline 3 & Tanah kosong dan properti lain & $20 \% \%$, atau $<$ \\
\hline
\end{tabular}

Sumber: IAAO

Untuk jenis properti lain dan personal property, target COD (koefisien dispersi) seharusnya merupakan cerminan dari kondisi yang sesungguhnya dari kondisi yang seharusnya dari property dan kondisi pasar, serta keberadaan dan indikator-indikator pasar yang lain.

\section{Studi Rasio}

Studi rasio merupakan alat utama yang digunakan untuk mengukur kinerja penilaian massal. Penilaian massal yang digunakan dalam PBB, harus menghasilkan penilaian yang 
akurat dan penetapan yang wajar atau adil. Keadilan yang dimaksudkan disini adalah bahwa pembebanan pajak merata pada objek-objek yang secara kuantitas dan kualitas adalah relatif sama. Supaya keadilan tersebut diterima semua pihak untuk segala kepentingan maka keakuratan penilaian tersebut harus standart, sebagaimana yang dimaksudkan standart IAAO yaitu pendapat penilai sama dengan kondisi di lapangan.

Studi rasio membandingkan nilai taksiran penilaian terhadap nilai pasar (Eckert et al. 1990:515). Nilai taksiran merupakan harga rata-rata dari berbagai nilai pasar objek penilaian pada suatu daerah tertentu dan pada saat tertentu. Nilai taksiran ini, yang dimaksudkan adalah NJOP, kemudian menjadi dasar dalam penentuan pajak PBB. Sedangkan nilai pasar merupakan harga yang paling mungkin secara tunai pada properti yang menghasilkan pasar kompetitif dan terbuka, yang mengasumsikan bahwa pembeli dan penjual mempunyai pengetahuan yang banyak terhadap pasar, cukup waktu untuk memperhitungkan penjualan, dan harga tidak dipengaruhi oleh kasus-kasus khusus. Dalam studi rasio, nilai pasar selalu direpresentasikan dengan Harga Jual Objek Pajak (HJOP), yaitu harga aktual yang terjadi secara terbuka. Transaksi yang tidak mempresentasikan pasar terbuka tidak digunakan dalam studi rasio.

\section{Perhitungan Rasio}

Rasio diformulasikan dengan membagi nilai taksiran/NJOP dengan nilai pasar/HJOP (Eckert et al. 1990:53). Contoh, sebidang tanah untuk tujuan pengenaan PBB dinilai Rp. 40.000.000,00 dan terjual pada Rp. 50.000.000,00 mempunyai rasio sebesar 0,80 atau 80\%:A/S = 40 juta/50 juta=0,80 dimana A adalah nilai taksiran (NJOP) dan S adalah nilai pasar (HJOP).

Studi rasio ini, di Indonesia, kemudian secara umum digunakan oleh penilai PBB sebagai alat evaluasi kinerja penetapan NJOP PBB, yang dikenal dengan assessment ratio (Hartoyo, 1995:1).

\section{Aspek-Aspek Kinerja Penetapan NJOP}

Menurut Eckert et al, studi rasio mengukur dua aspek utama yaitu level of appraisal dan level of uniformity. Keterangan masing-masing aspek kinerja penetapan NJOP adalah sebagai berkut:

\section{Pengukuran Level of Appraisal}

Pengukuran ini dihitung secara statistik, yang pertama dengan pengukuran tendensi sentral, yaitu perhitungan mean, median, dan weighted-mean dari suatu appraisal ratio, sehingga diketahui apakah NJOP lebih besar atau lebih kecil dari HJOP. Rumus pengukuran tendensi sentral : 


$$
\begin{aligned}
& A R_{\text {Mean }}=\frac{\sum(A / S)}{n} \\
& \mathrm{AR}_{\text {Med }}=0,5(\mathrm{n})+0,5 \\
& A R_{W-\text { MEan }}=\frac{\sum A}{\sum S}
\end{aligned}
$$

dimana A adalah nilai taksiran (NJOP), $\mathrm{S}$ adalah nilai pasar (HJOP), dan $\mathrm{n}$ adalah ukuran sampel observasi. Standart Appraisal Ratio (AR) yang sah untuk tingkat penetapan, sebagaimana rekomendasi IAAO, adalah $90 \%$ s/d 110\%, sedangkan :

a. Jika mean/median $>1,10$ berarti overappraisal.

b. Jika mean/median $>0,90$ berarti underappraisal.

c. Jika mean/w-mean $>1,10$ berarti regresif.

d. Jika mean/median $<0,90$ berarti progresif.

\section{Pengukuran Level of Uniformity}

Sedangkan pengukuran level of uniformity diperlukan untuk mengukur kinerja penetapan NJOP, yang tujuannya untuk menentukan perlu/tidaknya diadakan reappraisalsesuai skala prioritas berdasar kemampuan Kantor Pelayanan PBB dalam hal waktu, tenaga, dan dana.

Pengukuran keseragaman yang umum digunakan adalah koefisien dispersi (COD). Ini merupakan alat ukur statistik non-parametrik yang paling sering digunakan dalam studi rasio, yang mana pengukurannya menggunakan nilai median. Koefisien disperse (COD) dihitung dengan membagi deviasi absolut rata-rata dengan median dan mengalikan dengan 100 untuk mengkonversi rasio menjadi persentase. Jika dirumuskan adalah sebagai berikut:

$$
C O D=\frac{A A D}{A R_{\text {Med }}} X 100
$$

Dimana $\mathrm{AAD}=$ deviasi absolut rata-rata, dan $\mathrm{AR}_{\mathrm{Med}}=$ median dari $\mathrm{AR}$.

$$
A A D=\frac{\sum\left|A / S-A R_{M e d}\right|}{n}
$$

Semakin rendah COD, semakin tinggi tingkat keseragaman penetapan NJOP yang berarti pula properti-properti yang sejenis telah ditetapkan nilainya pada tingkat yang relatif seragam, dengan demikian mengidikasikan semakin baik kinerja penetapan NJOP tersebut. 
Aturan umum berkaitan dengan penggunaan COD, yaitu penetapan NJOP dikatakan baik jika $\mathrm{COD} \leq 15 \%$. Sedang berdasar jenis propertinya, standart IAAO mengenai COD adalah :

Perumahan
a. Baru
$\mathrm{COD} \leq 10 \%$
b. Lama
$\mathrm{COD} \leq 15 \%$

Bangunan Komersial
a. Perkotaan
$\mathrm{COD} \leq 15 \%$
b. Pedesaan
COD $\leq 20 \%$

Tanah kosong dan properti lainnya COD $\leq 20 \%$

Jika besar COD/COV melebihi aturan IAAO, maka tingkat keseragaman rendah/kinerja penetapan NJOP dikatakan jelek, dan harus dilakukan penilaian ulang.

\section{Pengujian Binomial Test}

Binomial test ini merupakan statistik non parametrik, dengan dasar nilai median. Penghitungan ini untuk menguji signifikasn hipotesis yang telah dibuat. Binomial test ini menghitung nilai $\mathrm{Z}$ dengan rumus :

$$
Z_{h i t}=\frac{0.5(n-1)-X}{\sqrt{0.25 n}}
$$

dimana $x$ =jumlah di atas atau di bawah median, pilihlah yang lebih kecil; dan $n=u k u r a n$ sampel.

\section{Teori Korelasi}

Lukas SA (1997:319) menjelaskan, penghitungan koefisien korelasi digunakan untuk mengetahui adanya hubungan linear antara satu variabel dengan variabel lain dalam suatu observasi. Variabel yang dimaksudkan adalah NJOP dan HJOP atas tanah (bumi). Berdasarkan teori yang ada maka hipotesis penelitian ini adalah:

H1: Diduga penetapan NJOP tanah (bumi) di Kelurahan dinoyo telah mendekati Standart IAAO

H2: Diduga penetapan NJOP tanah (bumi) di Kelurahan Merjosari telah mendekati Standart IAAO

H3: Diduga terdapat korelasi positif antara NJOP dan HJOP tanah (bumi) di Kelurahan Dinoyo 


\section{METODE PENELITIAN}

Kelurahan Merjoari dan Kelurahan Dinoyo Kecamatan Lowokwaru Kota Malang dipilih sebagai wilayah penelitian karena merupakan salah satu dari daerah di Jawa Timur yang mempunyai perkembangan (nilai tanah) dengan peningkatan secara nyata. Perkembangan nilai tanah di daerah ini dapat dilihat dari banyaknya transaksi jual beli tanah dan/atau bangunan baik yang tercatat di Laporan Trasaksi Jual Beli PPAT maupun yang hanya tercatat di kelurahan-kelurahan. Selain itu perkembangan daerah tempat tinggal dan daerah pendidikan yang besar.

Data dalam penelitian berasal dari data primer yang diperoleh dengan survey pada populasi objek pajak tanah (bumi) di Kelurahan Merjosari dan Kelurahan Dinoyo Kecamatan Lowokwaru Malang. Cara pemilian sampel dilakukan secara stratified random sampling dan bersifat convenience. Metode ini menitik beratkan pada klasifikasi tanah (bumi) menurut pajak, karena populasi yang diteli sangat banyak maka dilakukan dengan random. Sedangkan convenience sampling method pengambilan sampel ini didasarkan atas kemudahan dari sisi peneliti (Sevilla, 1993:169). Sebagai contoh, jika ingin mengevaluasi penetapan NJOP suatu objek pada suatu daerah, maka peluang kita hanya meneliti NJOP objek tersebut yang telah diketahui harga jualnya di pasaran. Kriteria sampel yang diambil juga memperhatikan perbandingan jumlah objek pajak tanah/bumi dengan kecukupan data penelitian

Data primer untuk penelitian, yang terdiri dari harga jual objek pajak (HJOP) merupakan harga pasar wajar tanah (bumi) yang berasal dari transaksi jual beli tanah yang terjadi selama tahun 2007 di Kota Malang, diperoleh dari hasil survey harga pasar wajar di daerah-daerah yang telah dijadikan objek penelitian.

Sedangkan data sekunder berupa nilai jual objek pajak (NJOP) tanah (bumi) yang merupakan ketetapan tahun 2007 dari kantor pelayanan PBB Malang. Data mengenai deskripsi umum wilayah penelitian dari Biro Pusat Statistik Kota Malang dan Pemerintah Kota Malang.

Objek penelitian adalah nilai tanah (bumi). Teknik pengumpulan data: data transaksi jual beli yang tercatat dalam laporan PPAT yang diserahkan ke Kantor PBB dikumpulkan, dicari Nomor Objek Pajak (NOP) dan NJOP-nya dan dicatat perwilayah Kelurahan berdasarkan klasifikasi, kemudian dicari HJOP yang merupakan harga pasar wajar dilapangan secara langsung dengan menggunakan interview dengan Wajib Pajak yang bersangkutan 
(penawaran), atau dengan penduduk sekitar wialayah objek yang diteliti, Kelurahan aparat desa, Badan Pertanahan Malang, Pengembang Properti, Jasa Properti, Taksiran Bank, yang kemudian diisikan kedalam Angket Data Nilai Tanah.

Instrumen pengukuran yang digunakan dalam penelitian ini adalah instrumen yang sudah dikembangkan oleh peneliti-peneliti terdahulu.

a. Variabel NJOP, yaitu nilai jual objek pajak, yang diperoleh dari data di Kantor Pelayanan Pajak Bumi dan Bangunan Malang atas objek pajak tanah (bumi) di Kelurahan Merjosari dan Kelurahan Dinoyo Kota Malang.

b. Variabel HJOP, yaitu Harga Jual Objek Pajak, yang diperoleh dari Wajib Pajak yang bersangkutan (penawaran), atau dengan penduduk sekitar wialayah objek yang diteliti, Kelurahan aparat desa, Badan Pertanahan Malang, Pengembang Properti, Jasa Properti, Taksiran Bank, atas objek pajak tanah (bumi) di Kelurahan Merjosari dan Kelurahan Dinoyo Malang.

\section{HASIL DAN PEMBAHASAN}

\section{Keadaan Umum Wialayah Penelitian}

Kelurahan Merjosari dan Kelurahan Dinoyo Kecamatan Lowokwaru dipilih sebagai wilayah penelitian karena merupakan daerah dengan perkembangan nilai tanah (bumi) yang mengalami peningkatan secara nyata. Hal ini disebabkan oleh banyaknya pendatang sebagai mahasiswa dan pekerja,. banyaknya transaksi jual beli tanah dan/atau bangunan baik yang tercatat di Laporan Trasaksi Jual Beli PPAT, Pengembang properti, jasa properti maupun kantor Kelurahan, pembangunan tempak pendidikan baik dari taman kanak-kanak samapai perguruan tinggi, pembangunan perumahan baik pengembang atau institusional, pusat perdagangan.

Kantor Pelayanan PBB Malang telah memasukkan daerah ini menjadi daerah prioritas pelaksanaan pendataan objek dan subjek pajak melalui sistem Manajemen dan Informasi Perpajakan (SISMIOP) yang bermanfaat bagi pelaksanaan penilaian massal dengan bantuan komputer.

Kecamatan Lowokwaru terdiri dari 12 Kelurahan, 115 RW, dan 683 RT. Luas wilayah kecamatan Lowokwaru adalah 2089,513Ha. Secara geografis kecamatan ini berada datran tinggi 
dari permukaan laut $(460 \mathrm{~m})$ suhu Max/Min $20^{\circ} \mathrm{C}$ sampai dengan $28^{\circ} \mathrm{C}$, curah hujan rata-rata $2.71 \mathrm{~mm}$.

\section{Diskripsi Klasifikasi Tanah dan Bangunan}

Untuk memudahkan penghitungan Pajak Bumi dan Bangunan (PBB) yang terutang atas suatu objek pajak berupa tanah (bumi) dan atau bangunan perlu diketahui pengelompokkan objek pajak menurut nilai jualnya, tarif, Nilai Jual Objek Pajak Tidak Kena Pajak (NJOPTKP), dan Nilai Jual Kena Pajak (NJKP). Pengelompokkan objek pajak menurut nilai jual lazim disebut dengan klasifikasi tanah (Bumi).

Ada dua kelompok klasifikasi, penggolongan dan ketentuan nilai jual bumi, yaitu Kelompok A dan Kelompok B. Dari penelitian yang dilakukan berdasarkan objek penelitian di Kelurahan Merjosari dan Kelurahan Dinoyo Kecamatan Lowokwaru masuk Kelompok A dari Kelas A17 dengan nilai jual permukaan tanah > Rp 784.000-Rp 855.000 dengan rata-rata nilai jual $\left(\mathrm{RP} / \mathrm{M}^{2}\right)$ sebesar Rp 802.000 sampai kelas A30 dengan nilai jual permukaan tanah > Rp 73.000-Rp 91.000 dengan rata-rata nilai jual (RP/M²) sebesar Rp 82.000.

\section{Nilai Jual Objek Pajak Tidak Kena Pajak (NJOPTKP)}

Nilai Jual Objek Pajak Tidak Kena Pajak (NJOPTKP) mulai 1 Januari 2001 untuk setiap daerah ditetapkan setinggi-tingginya Rp 12.000 .000 untuk tiap wajib pajak (WP). Apabila Wajib pajak mempunyai lebih dari satu objek pajak, maka yang mendapatkan NJOPTKP hanya satu objek, yaitu yang nilainya paling tinggi.

\section{Diskripsi Permasalahan Pajak Bumi dan Bangunan}

Permasalahan pajak bumi dan bangunan di Kecamatan Lowokwaru adalah penentuan nilai jual obejk pajak (NJOP) yang ditentukan kantor pelayanan pajak bumi dan bangunan tentunya akan digunakan sebagai dasar transaksi-transaksi ekonomi yang lain, seperti jual beli tanah dan atau bangunan, pengembang, penentuan keuntungan bagi jasa properti, pengajuan kredit, dan lain-lain. Hal ini menjadi permasalahan karena hasil wawancara peneliti yang dilakukan terhadap Kantor Pelayanan Pajak Malang, penentuan NJOP berdasarkan data dari penawaran, pengembang, jasa properti, petugas pajak, tapi data dari kelurahan atau desa tidak digunakan sebagai dasar penentuan NJOP. Untuk itu peneliti dalam pengambilan data 
menggunakan data yang lebih luas yaitu desa, kelurahan, pengembang, jasa properti, Badan Pertanahan Nasional (BTN), dan Penawaran.

Data yang dianalisa dalam studi rasio adalah Harga Jual Objek Pajak/HJOP tanah (bumi) yang merupakan market values, dan Nilai Jual Objek Pajak/NJOP tanah (bumi) yang merupakan appraisal values. Dengan metode stratified random sampling dan Conventional, jumlah sampel yang terpilih sebanyak 154 sampel untuk kelurahan Dinoyo dan 221 sampel untuk kelurahan Merjosari,

\section{Studi Rasio}

Dari hasil perhitungan rasio NJOP terhadap HJOP atas tanah (bumi) di Kelurahan Dinoyo, menujukkan bahwa penggunaan harja jual rata-rata untuk menentukan besarnya Nilai Jual Objek Pajak/NJOP menghasilkan penetapan yang tidak selalu sama dengan nilai pasar Harga Jual Objek Pajak/HJOP, sampel dari objek pajak yang diteliti dalam penelitian ini menujukkan bahwa HJOP>NJOP sebanyak 143 data (92.9\%); HJOP<NJOP sebanyak 11 data (7,1\%) Hal ini menujukkan bahwa appraisal values Kelurahan Dinoyo Kecamatan Lowokwaru Kota Malang lebih kecil dari market valuenya.

Sedangkan hasil pengujian rasio di Kelurahan Merjosari, menujukkan bahwa penggunaan harja jual rata-rata untuk menentukan besarnya Nilai Jual Objek Pajak/NJOP menghasilkan penetapan yang tidak selalu sama dengan nilai pasar Harga Jual Objek Pajak/HJOP, sampel dari objek pajak yang diteliti dalam penelitian ini menujukkan bahwa HJOP>NJOP sebanyak 214 data (96.83\%); HJOP<NJOP sebanyak 7 data (3.17\%) Hal ini menujukkan bahwa appraisal values Kelurahan Merjosari Kecamatan Lowokwaru Kota Malang lebih kecil dari market valuenya.

\section{Perhitungan Tendensi Sentral NJOP Terhadap HJOP Tanah (Bumi)}

Hasil perhitungan tendensi sentral dengan menggunakan data rasio menggunakan alat bantu SPSS for Windows Ver. 12.01, tampak sebagai berikut:

Tabel 2: Tendensi Sentral untuk Kelurahan Dinoyo

\begin{tabular}{|l|r|}
\hline \multicolumn{1}{|c|}{ Tendensi Sentral } & Nilai \\
\hline ARMean & 0.6740 \\
\hline AR Median & 0.6400 \\
\hline ARW-Mean & 0.6952 \\
\hline
\end{tabular}




\begin{tabular}{|l|r|}
\hline Mean/Med & 1.0531 \\
\hline Mean/W-Mean & 0.9696 \\
\hline AAD & 0.1609 \\
\hline COD & 25.1446 \\
\hline
\end{tabular}

Mean

$$
\text { ARMean }=\frac{103.66}{154}=0.6731
$$

\section{Median}

Dengan SPSS diskriptif frekuensi, tampak bahwa nilai median NJOP/HJOP, yaitu sebesar 0.6400 , lampiran 3

\section{Weighted Mean}

$$
\begin{aligned}
& \mathrm{AR}_{\text {W-Mean }}=\frac{\text { Mean }}{\text { WMean }} \\
& \text { Wmean }=\sum \frac{\text { NJOP }}{\text { HJOP }}=\sum \frac{37.124 .000}{53.750 .000}=0.6907
\end{aligned}
$$

Dari hitungan tersebut dapat diketahui yaitu, ratio:

\section{Mean/Median}

$$
\text { Mean/Median }=\frac{0.6731}{0.6400}=1.0517
$$

Dari rasio Mean/Median menunjukkan bahwa NJOP telah memenuhi standard (IAAO) yang sah, dengan kata lain tidak terjadi overappraisal atau underappraisal, hal ini ditunjukkan dengan nilai ratio mean/median sebesar 1.0517 masih dalam batas standard IAAO $(0.90 \leq$ Mean/Median $\leq 1.10)$.

Hasil analisa rasio untuk Kelurahan Dinoyo sebesar 1.0517 menunjukkan bahwa antara NJOP yang menjadi appraisal value yang telah ditentukan oleh Kantor Pelayanan Pajak Bumi Dan Bangunan Malang telah sesuai penilaiannya dengan HJOP yang menjadi market value di 
Kelurahan Dinoyo, sehingga NJOP yang ada dapat digunakan untuk segala kepentingan (bank, jual beli tanah, penentuan pajak Bumi dan Bangunan).Hal ini dapat disimpulkan level of appraisal kelurahan Dinoyo Kecamatan Lowokwaru tahun 2006 telah memenuhi standard yang sah, sehingga dikatakan penetapan NJOP di daerah teresebut telah adil untuk semua kepentingan.

Hasil perhitungan tendensi sentral dengan menggunakan data rasio kelurahan Merjosari tampak dalam tabel berikut:

Tabel 3: Tendensi Sentral untuk Kelurahan Merjosari

\section{Median}

\begin{tabular}{|l|r|}
\hline \multicolumn{1}{|c|}{ Tendensi Sentral } & Nilai \\
\hline ARMean & 0.5994 \\
\hline AR Median & 0.5330 \\
\hline ARW-Mean & 0.5201 \\
\hline Mean/Med & 1.1245 \\
\hline Mean/W-Mean & 1.1523 \\
\hline AAD & 0.1605 \\
\hline COD & 30.1201 \\
\hline
\end{tabular}

Dengan SPSS diskriptif frekuensi, tampak bahwa nilai median NJOP/HJOP, yaitu sebesar 0.5330

\section{Weighted Mean}

$$
\begin{aligned}
& \mathrm{AR}_{\text {W-Mean }}=\frac{\text { Mean }}{\text { WMean }} \\
& \text { Wmean }=\sum \frac{\text { NJOP }}{\text { HJOP }}=\sum \frac{25.344 .000}{48.725 .000}=0.5201
\end{aligned}
$$

Dari hitungan tersebut dapat diketahui yaitu, ratio:

\section{Mean/Median}

$$
\text { Mean } / \text { Median }=\frac{0.5994}{0.5330}=1.1245
$$

Dari rasio Mean/Median menunjukkan bahwa NJOP telah belum memenuhi standard (IAAO) yang sah, dengan kata lain terjadi overappraisal atau underappraisal, hal ini ditunjukkan 
dengan nilai ratio mean/median sebesar 1.1245 diluar batas standard IAAO $(0.90 \leq$ Mean/Median $\leq 1.10)$.

Hasil analisa rasio menunjukkan bahwa penetapan NJOP belum memenuhi standard (IAAO) yang sah, atau terjadi regresif, yaitu nilai rasio Mean/Weighted-Mean > 1.10, selain itu level of appraisal Kelurahan Merjosari Kecamatan Lowokwaru tahun 2006 belum memenuhi standard yang sah, sehingga dikatakan penetapan NJOP di daerah teresebut belum adil, yaitu penentuan NJOP yang ditentukan oleh Kantor Pelayanan Pajak Bumi dan Bangunan Malang belum sesuai dengan HJOP sebagai market value. Sehingga NJOP belum dapat digunakan sebagai data penentu keputusan berbagai kepentingan (bank, jual beli tanah)

\section{Analisis Binomial Test Non Parametrik NJOP Terhadap HJOP}

Setelah melakukan analisa rasio, maka untuk melakukan pengujian hipotesis dilakukan analisis binomial test non parametrik. Hasil uji normalitas data menunjukkan bahwa data tidak berdistribusi normal maka alat analisis yang digunakan adalah binomial test non parametric.

Hasil binomial test menunjukkan bahwa untuk kelurahan Dinoyo nilai Asym. Sig. (2tailed $)<\alpha(0.044<0,05)$, sehingga Ho ditolak dan $\mathrm{H}_{1}$ diterima, maka pernyataan penetapan NJOP sudah adil/wajar. Kesimpulan dari binomial test adalah penetapan NJOP tahun 2006 di Kelurahan Dinoyo Kecamatan Lowokwaru secara nyata dinilai sudah adil bagi semua pihak, dan untuk semua kepentingan.

Sedangkan di Kelurahan Merjosari juga sama yaitu telah secara nyata nilai sudah adil bagi semua pihak, dan untuk semua kepentingan, hal ini ditunjukkan dengan nilai Asym. Sig. (2-tailed) $<\alpha(0.003<0,05)$, sehingga Ho ditolak dan $\mathrm{H}_{1}$ diterima.

Dari hasil uji binomial tes menunjukkan bahwa telah ada keseragaman penentuan NJOP tanah (bumi) oleh Kantor Pelayanan PBB Malang dalam satu klasifikasi kelas pajak dibandingkan dengan HJOP sebagai market value baik di Kelurahan Dinoyo atau Kelurahan Merjosari.

\section{Perhitungan COD (Koefisien Dispersi)}

COD (Koefisien Dispersi) digunakan untuk mengetahui uniformity level (tingkat keseragaman). Hasil analisis COD di kelurahan Dinoyo menunjukkan nilai COD sebesar 25.15\% yaitu, 


$$
\mathrm{COD}=\frac{0.1659}{0.6400} \times 100=25.15 \%
$$

Dengan demikian penetapan NJOP tanah (bumi) pada Kelurahan Dinoyo Kecamatan Lowokwaru tahun 2006, uniformity level-nya menunjukkan rendah, karena koefisien variasinya melebihi prosentase yang direkomendasikan IAAO yaitu sebesar $20 \%$.

Sedangkan nilai COD di Kelurahan Merjosari sebesar 30.12\% lebih besar dari Kelurahan Dinoyo,

$$
\mathrm{COD}=\frac{0.1659}{0.5330} \times 100=30.12 \%
$$

Dengan demikian penetapan NJOP tanah (bumi) pada Kelurahan Merjosari Kecamatan Lowokwaru tahun 2006, uniformity level-nya menunjukkan rendah, karena koefisien variasinya melebihi prosentase yang direkomendasikan IAAO yaitu sebesar $20 \%$.

Kesimpulan yang dapat diambil adalah tingkat keseragaman penetapan NJOP Kelurahan Dinoyo dan Kelurahan Merjosari Kecamatan Lowokwaru Kota Malang Tahun 2007 secara nyata rendah, hal ini berarti menghasilkan kinerja penetapan NJOP yang tidak baik. Maka penetapan NJOP daerah tersebut perlu dilakukan penilaian ulang.

\section{Analisa Korelasi NJOP dan HJOP Tanah (Bumi)}

Analisa korelasi digunakna untuk mengetahui hubungan antara NJOP sebagai appraisal value dengan HJOP sebagai market values. Dari hasil uji normalitas data tampak bahwa data tidak berdistribusi normal, maka analisis yang digunakan adalah rank spearmen correlation (non parametrik).

Tabel 4: Analisa Korelasi NJOP dan HJOP Kelurahan Dinoyo dan Kelurahan Merjosari

\begin{tabular}{|l|r|r|}
\hline Keterangan & NJOP Dyn_HJOP Dyn & NJOP Mjr_HJOP Mjr \\
\hline Coefisien Cor. & .854 & .642 \\
\hline Sig. & .000 & .000 \\
\hline $\mathrm{N}$ & 154 & 221 \\
\hline
\end{tabular}

Dari tabel diatas menunjukkan bahwa ada korelasi positif NJOP dan HJOP di Kelurahan Dinoyo sebesar 85.4\%. Dan signifikan pada tingkat $\alpha=0,01$ atau nilai prob. $<\alpha(0,000<0,01)$, maka Ho ditolak dan Ha diterima. 
Sedangkan di Kelurahan Merjosari menunjukkan bahwa ada korelasi positif NJOP dan HJOP sebesar $64.2 \%$. Dan signifikan pada tingkat $\alpha=0,01$ atau nilai prob. $<\alpha(0,000<0,01)$, maka Ho ditolak dan Ha diterima.

\section{Uji Beda Appraisal Level NJOP terhadap HJOP}

Hasil uji beda appraisal level NJOP terhadap HJOP pada kelurahan Dinoyo dan Kelurahan Merjosari menunjukkan hasil yang tidak signifikan, yaitu nilai prob> $\alpha(0.998>0.05)$. Hal ini menunjukkan bahwa tidak ada keseragaman penetapan NJOP dibandingkan dengan HJOP baik di kelurahan Dinoyo atau Kelurahan Merjosari.

\section{SIMPULAN}

Setelah dilakukan analisis appraisal level, diperoleh hasil bahwa tingkat penetapan NJOP tanah (bumi) di Kelurahan Dinoyo Kecamatan Lowokwaru Kota Malang Tahun 2006 sudah berada dalam kriteria adil atau tidak terjadi overappraisal dan underappraisal. Hal ini tampak dalam hasil analisis rasio dari mean/median yang menunjukkan perbandingan NJOP terhadap HJOP sebesar 1,0531 dan mean/weighted-mean sebesar 0.9696 yang berarti terletak pada interval antara 0.90-1.10 sehingga dikatakan sudah adil karena nilai interval mean/weightedmean sudah sesuai dengan persyaratan standard penetapan NJOP yang adil $(0,90-1,10)$. Kemudian bila dilihat dari pengujian binomial test, menunjukkan bahwa hipotesis yang diajukan diduga penetapan NJOP di Kelurahan Dinoyo adalah baik dan sudah adil untuk seluruh kepentingan.

Di Kelurahan Merjosari Hal ini tampak dalam hasil analisis rasio dari mean/median yang menunjukkan perbandingan NJOP terhadap HJOP sebesar 1.1245 dan mean/weightedmean sebesar 1.1523 yang berarti lebih dari 1.10 sehingga dikatakan belum adil karena nilai interval mean/weighted-mean belum sesuai dengan persyaratan standard penetapan NJOP yang adil (0,90-1,10). Kemudian bila dilihat dari pengujian binomial test, menunjukkan bahwa hipotesis yang diajukan diduga penetapan NJOP di Kelurahan Dinoyo adalah baik dan sudah adil untuk seluruh kepentingan

Hasil analisis uniformity level menujukkan bahwa tingkat keseragaman NJOP tanah (bumi) di Kelurahan Dinoyo dan Kelurahan Merjosari Kecamatan Lowokwaru Kota Malang tahun 2006 berada pada level yang rendah. Hal ini dilihat dari dispersi NJOP yang tinggi yaitu sebesar 25.15\% untuk Kelurahan Dinoyo dan 30.12\% di Kelurahan Merjosari yangs emuanya 
berada diatas dispersi yang dipersyaratkan, yaitu nilai COD tidak lebih dari 20\%. Jadi dapat disimpulkan bahwa kualitas penetapan NJOP tersebut adalah tidak baik.

Dari hasil analisis korelasi dengan rank spearmen menujukkan hasil bahwa ada hubungan positif antara NJOP dengan HJOP dan signifikan. Hal ini mengindikasikan bahwa HJOP yang merupakan market value menjadi ekspresi nilai pasar yang harus diperhatikan guna menghasilkan penetapan NJOP yang lebih akurat. Sehingga perlu evaluasi dan pemantauan terhadap perkembangan harga tanah di Kelurahan Dinoyo dan Kelurahan Merjosari Kecamatan Lowokwaru.

\section{DAFTAR PUSTAKA}

Aris. 2005. Evaluasi Penetapan NJOP Tanah Kosong di Tulungaggung. Malang

Anonim.1994. Undang-Undang Nomor 12 Tahun 1994 Tentang Pajak Bumi dan Bangunan. Direktorat Jendral Pajak, Jakarta.

Anonim. 2000. Surat Keputusan Direktur Jendral Pajak Nomor: Kependataan, Penilaian Objek dan Subjek PBB dalam rangka pembentukan dan pemeliharaan basis data SISMIOP, Direktorat PBB. Jakarta.

Anonim. 1997. Undang-Undang Nomor 21 Tahun 1997 Tentang Bea Perolehan Hak Atas Bumi dan Bangunan, Direktorat Jendral Pajak, Jakarta.

Anonim.1994. Undang-Undang Nomor 12 Tahun 1997 Tentang Bea Perolehan atas Tanah dan Bangunan, Direktorat Jendral Pajak, Jakarta

Chaizi Nasucha, Cepi D Sutman, Sigit Henryanto, M. Icchsan Ali.1999. Solusi Perpajakan Terlengkap. Majalah Berita Pajak Dan Ikatan Sarjana Ekonomi Indonesia

Departemen Keuangan. 2004. Tax Guide, Jakarta

Eckert, Joseph, K, Glaudemans, Robert, J. Almy Richard, R. 1990. Property Appraisal and Assesemnet, IAAO, Chicago.

Hartoyo. 1995. Assesment Sales Ratio Suatu alat Pengukuran Kinerja Penilaian Dalam Pelaksanaan PBB. Jurnal Value Estate. Volume Ke-2

Kota Malang, www / / pemkot.malang.go.id

Mardiasmo. Perpajakan. Edisi Revisi. Yogyakarta 
Mawad Sri Basuki. 1999. Analisis Assesement Ratio sebagai alat uji akurasi NJOP Bumi, Jurnal Survei dan Penilaian Properti, Vol. Ke-15

Styono.2000. Evaluasi Penetapan NJOP Tanah Kosong.Yogyakarta

Singgih Santoso. 2001. SPSS Statistik Non Parametrik. PT Elex Media Komputindo, Jakarta.

Singgih Santoso. 2000. SPSS Statistik Parametrik. PT Elex Media Komputindo, Jakarta. 